\title{
Use of satellite data to assess the impacts of irrigation withdrawals on Upper Klamath Lake, Oregon
}

\author{
Q. Tang, E. A. Rosenberg, and D. P. Lettenmaier \\ Dept. of Civil and Environment Engineering, University of Washington, Seattle, WA, USA
}

Received: 6 February 2009 - Published in Hydrol. Earth Syst. Sci. Discuss.: 27 February 2009

Revised: 9 May 2009 - Accepted: 14 May 2009 - Published: 20 May 2009

\begin{abstract}
Competition for scarce water resources in the Upper Klamath River Basin, Oregon has generated conflict among its stakeholders, as demonstrated by recent regulations on withdrawals from Upper Klamath Lake. Information on agricultural water usage can help assess the hydrologic impacts of irrigation and support operational decisions. This paper presents an experimental satellite-based evapotranspiration estimation system that is combined with the Variable Inflitration Capacity (VIC) hydrological model to estimate irrigation consumption, which is then used to assess the effects of irrigated agriculture on lake storage volumes and water levels. The hydrological model is calibrated with streamflow observations and used to estimate unmeasured lake inflows and guide water budget calculations. When combined with the VIC model, the satellite-based evapotranspiration estimation system shows that irrigation caused a decline of $0.3 \mathrm{~m}$ in average annual water levels and $0.5 \mathrm{~m}$ in mean October water levels, and an increase of $0.5 \mathrm{~m}$ in annual water level ranges at the lake from 2001 to 2005 . The results demonstrate the potential of satellite data for agricultural water resource management at the regional scale.
\end{abstract}

\section{Introduction}

Globally, about $67 \%$ of water withdrawals from streams, reservoirs, and lakes are used for irrigation, accounting for $87 \%$ of the world's consumptive water use (withdrawal minus return flow) and more than $40 \%$ of its food supply (Döll and Siebert, 2002). Despite the benefits of irrigation for food production, its impacts on the environment have become of increasing concern. Sustainable management of water resources is required to balance the needs of irrigated agricul-

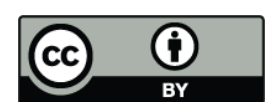

Correspondence to: D. P. Lettenmaier (dennisl@u.washington.edu) ture against those of the natural environment. The value of management strategies is in turn dependent on the availability of adequate information about potential water supplies, irrigation demands, and other hydrometeorological conditions at scales ranging from farm fields to river basins.

Estimates of evapotranspiration (ET) from irrigated land can be used as a proxy for agricultural water consumption and allow the assessment of agricultural impacts on streamflow and water bodies. At the regional scale, advanced tools that are available to aid in these estimates include satellite remote sensing data and hydrological models. Hydrological models typically estimate ET through a water balance that represents the linkage of hydrological processes such as precipitation, runoff, and soil moisture (e.g. Liang et al., 1994; Tang et al., 2006, 2007). Most hydrological models simulate "natural" conditions, that is, the interaction of land surface hydrological processes that would occur in the absence of water management by diversions from streams, return flow, and reservoir storage. In principle, spatially distributed hydrological models could be applied to environments influenced by man, if sufficient data were available to quantify the artificial movement and storage of water. In general, though, estimates of large-scale water consumption patterns are limited by the availability of local observations, particularly in irrigated areas containing regulated, but often ungauged, flow in natural and manmade channels. Satellite data offer opportunities to map actual water consumption in large areas, including those regions where measured hydrometeorologic data may be sparse (Engman, 1995), reducing or eliminating the need for detailed knowledge of local water supply systems.

Despite substantial research activity in the estimation of ET via remote sensing (e.g. Nemani and Running, 1989; Bastiaanssen et al., 1998; Stewart et al., 1999; Bastiaanssen et al., 2002; Nishida et al., 2003; Neale et al., 2005), few reports of applications of these methods to regional-scale agricultural water management exist (Bastiaanssen et al., 2000).

Published by Copernicus Publications on behalf of the European Geosciences Union. 


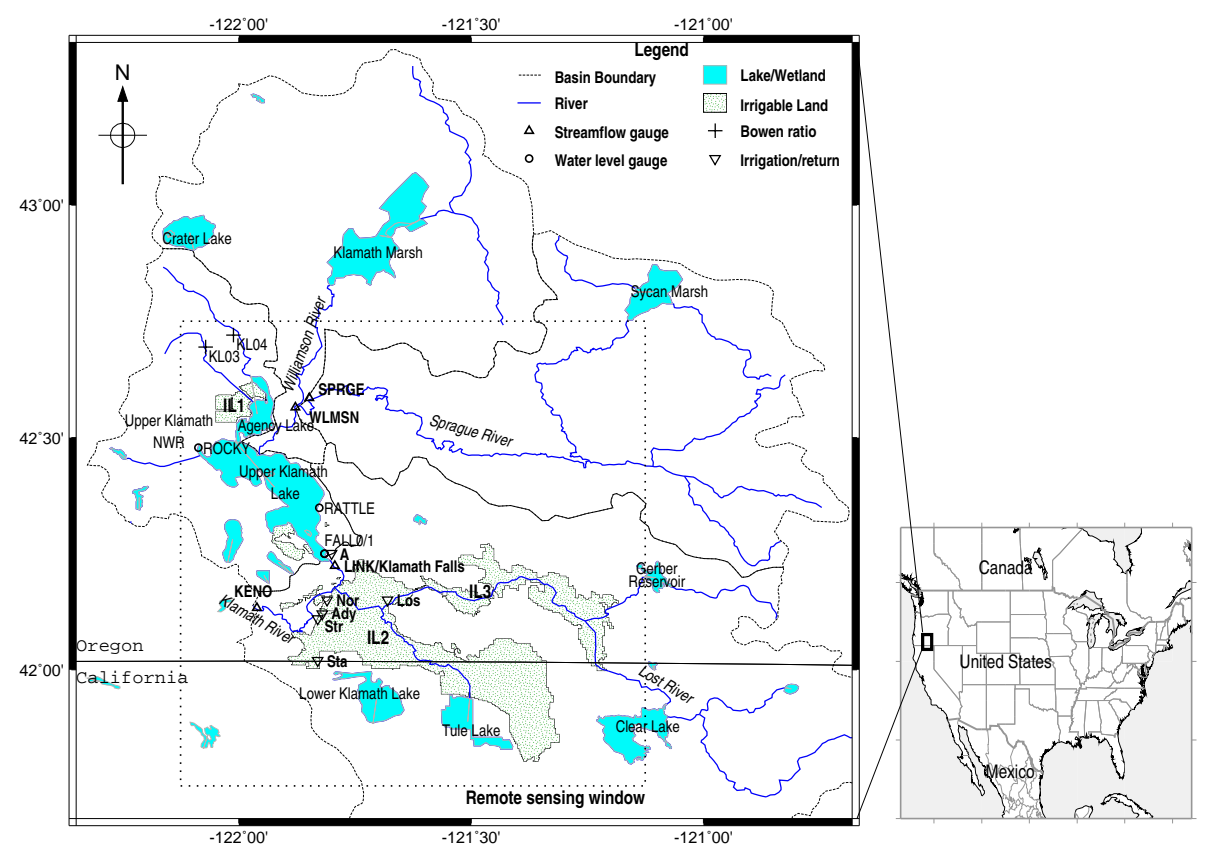

Fig. 1. Upper Klamath River Basin and the remote sensing window (dotted line) in which the satellite-based ET estimation system was implemented.

Two factors pose serious constraints to the operational adoption of remote sensing technology in water resources management. First, the spatial and temporal resolution of sensors that provide information in near real-time is often too coarse to provide useful data on crop water use (Cleugh et al., 2007; Mu et al., 2007). Second, remote sensing estimates of ET are seldom directly comparable to groundbased meteorological observations and streamflow measurements. To address the first constraint, Tang et al. (2009b) developed a satellite-based ET estimation system based on MODIS (MODerate Resolution Imaging Spectroradiometer) and NOAA/NESDIS Surface Radiation Budget (SRB) products. With daily observations at spatial resolutions as high as $250 \mathrm{~m}$, MODIS provides remote sensing data that are suitable for the operational environment. The system presently runs in an experimental mode at the University of Washington (http://www.hydro.washington.edu/forecast/rset_ca/). The second constraint can be addressed by using hydrological models to bridge the gap between remote sensing-based and ground-based measurements of ET.

This paper assesses the impacts of irrigation on regional hydrology through a combination of remote sensing and hydrological modeling techniques. ET estimates based on remote sensing data are used to calculate net irrigation consumption for irrigated areas within the Klamath River basin that are supplied with water from the Upper Klamath Lake. The irrigation consumption estimates are then used in conjunction with reservoir inflow information to assess irrigation-related variations in the lake water depth. An in- troduction to the study area and data sources is provided in Sect. 2, followed by a description of the experimental methodology in Sect. 3. Results and evaluations are given in Sect. 4. The paper concludes with a discussion on the potential of satellite-based techniques in agricultural water resources management.

\section{Study area and data}

The Klamath River, draining $40795 \mathrm{~km}^{2}$ of south-central Oregon and north-central California, has become a focal point for local and national discussions on water management and scarcity (Powers et al., 2005). The Upper Klamath River Basin is managed by the US Bureau of Reclamation's (USBR) Klamath Project, which provides irrigation water to about $1000 \mathrm{~km}^{2}$ of irrigable land (IL) divided into three main areas of about 50, 700, and $250 \mathrm{~km}^{2}$ (IL1, IL2, and IL3, respectively, in Fig. 1). Sources of Project water include Upper Klamath Lake, Klamath River, Clear Lake Reservoir, Gerber Reservoir, and the Lost River, which flows within a closed basin at the southeast corner of the watershed. The Lost River Diversion Channel connects the Lost River to the Klamath River, which flows out of Upper Klamath Lake. Upper Klamath Lake provides water to IL1 and IL2, a portion of which is transferred through the Klamath River and Lost River Diversion Channel. Clear Lake Reservoir and Gerber Reservoir typically provide water to IL3 through the Lost River, although the Diversion Channel has the potential to 
Table 1. Sources of streamflow data, water level and storage data at Upper Klamath Lake, and irrigation/return flow data for IL2.

\begin{tabular}{|c|c|c|c|c|c|}
\hline Data Type & Name & ID & $\begin{array}{l}\text { Observation } \\
\text { Period } \\
(\mathrm{mm} / \mathrm{dd} / \mathrm{yyyy})\end{array}$ & Time frequency & Remarks \\
\hline Streamflow & WLMSN & $\begin{array}{l}\text { USGS } \\
11502500\end{array}$ & $\begin{array}{l}10 / 1 / 1917- \\
1 / 31 / 2008\end{array}$ & Daily & Headwater of the lake \\
\hline Streamflow & SPRGE & $\begin{array}{l}\text { USGS } \\
11501000\end{array}$ & $\begin{array}{l}3 / 1 / 1921- \\
1 / 31 / 2008\end{array}$ & Daily & Headwater of the lake \\
\hline Streamflow & LINK & $\begin{array}{l}\text { USGS } \\
11507500\end{array}$ & $\begin{array}{l}10 / 1 / 1961- \\
1 / 31 / 2008\end{array}$ & Daily & Downstream of the lake \\
\hline Streamflow & KENO & $\begin{array}{l}\text { USGS } \\
11509500\end{array}$ & $\begin{array}{l}6 / 1 / 1904- \\
1 / 31 / 2008\end{array}$ & Daily & Downstream of the lake \\
\hline Water level & ROCKY & $\begin{array}{l}\text { USGS } \\
11505800\end{array}$ & $\begin{array}{l}9 / 13 / 1973- \\
1 / 31 / 2008\end{array}$ & Daily & At the lake \\
\hline Water level & RATTLE & $\begin{array}{l}\text { USGS } \\
11505900\end{array}$ & $\begin{array}{l}9 / 13 / 1973- \\
1 / 31 / 2008\end{array}$ & Daily & At the lake \\
\hline Water level & FALL0 & $\begin{array}{l}\text { USGS } \\
11507000\end{array}$ & $\begin{array}{l}10 / 1 / 1969- \\
1 / 31 / 2008\end{array}$ & Daily & At the lake \\
\hline Water level & FALL1 & $\begin{array}{l}\text { USGS } \\
11507001\end{array}$ & $\begin{array}{l}10 / 1 / 1974- \\
1 / 31 / 2008\end{array}$ & Daily & At the lake \\
\hline Water Storage & KLM & CDEC KLM & $\begin{array}{l}10 / 1954 \\
1 / 2008\end{array}$ & Monthly & At the lake \\
\hline Irrigation & A & "A" Canal & $\begin{array}{l}1 / 1 / 2001- \\
12 / 31 / 2005\end{array}$ & Daily & $\begin{array}{l}\text { Conveys water from Upper Kla- } \\
\text { math Lake to IL2 }\end{array}$ \\
\hline Irrigation/return flow & Los & $\begin{array}{l}\text { Lost River Di- } \\
\text { version Channel }\end{array}$ & $\begin{array}{l}1 / 1 / 2001- \\
12 / 31 / 2005\end{array}$ & Daily & $\begin{array}{l}\text { Includes several diversions and } \\
\text { return flows (see Risley et al., } \\
\text { 2006). }\end{array}$ \\
\hline Irrigation & Nor & North Canal & $\begin{array}{l}1 / 1 / 2001- \\
12 / 31 / 2005\end{array}$ & Daily & $\begin{array}{l}\text { Conveys water from Klamath } \\
\text { River to IL2 }\end{array}$ \\
\hline Irrigation & Ady & Ady Canal & $\begin{array}{l}1 / 1 / 2001- \\
12 / 31 / 2005\end{array}$ & Daily & $\begin{array}{l}\text { Conveys water from Klamath } \\
\text { River to IL2 }\end{array}$ \\
\hline Return flow & Str & Straits Drain & $\begin{array}{l}1 / 1 / 2001- \\
12 / 31 / 2005\end{array}$ & Daily & Conveys drainage from IL2 \\
\hline Return flow & Sta & $\begin{array}{l}\text { Ady Canal State- } \\
\text { line }\end{array}$ & $\begin{array}{l}1 / 1 / 2001- \\
12 / 31 / 2005\end{array}$ & Daily & $\begin{array}{l}\text { Provides water to Lower Klamath } \\
\text { Lake }\end{array}$ \\
\hline
\end{tabular}

supplement IL3's supply with water from Upper Klamath Lake (USBR, 2005; Risley et al., 2006).

Upper Klamath Lake is a large, shallow freshwater lake that has been regulated as part of the Project since 1919, when the natural lake was diked to establish a new perimeter for its open water surface. The lake's surface elevation fluctuates from 1261 to $1264 \mathrm{~m}$ due to regulation of its water supply. The lake has a surface area of $271 \mathrm{~km}^{2}$ (including Agency Lake). Several large marshes, including Upper Klamath National Wildlife Refuge (NWR), are located at its margins, although the area of these marshes has been greatly reduced as a result of diking and water level management.

Water level fluctuations are an important factor in emergent vegetation species composition and dynamics. Persistently high lake levels may lead to a substantial reduction in the extent of wetlands and to the dominance of species relatively tolerant to constant water depths. Low lake levels may have adverse consequences by exposing wetland floors. The effects of widely varying water levels are less well known (USFWS, 2001a). Water levels have become a focus of recent biological assessments, generating conflict among various interest groups, including farmers, commercial and sport fishermen, federal wildlife refuge managers, environmental groups, and state, local, and tribal governments (USFWS, 2001a; USBR, 2002; Lewis, 2003; NRC, 2004, 2008). In a very dry period in 2001, the US District Court stopped water deliveries to farms in the irrigation area to preserve adequate water levels for the protection of two endangered species of Mullet fish (also known as suckers). The effect of irrigation on lake water levels is therefore not only of scientific interest, but carries political implications as well.

Daily water level observations of Upper Klamath Lake are available from the US Geological Survey (USGS), and monthly lake storage data can be found at the California Data Exchange Center (CDEC) (Table 1). Stage-storage relationships for the lake were developed from monthly averaged water level and water storage data (Fig. 2). These relationships were then applied to the daily water level observations to estimate daily storage volumes within the lake. Estimated daily storage volumes are plotted in Fig. 3, and show good agreement with the monthly storage data from CDEC. Two USGS streamflow stations (WLMSN and SPRGE) are located near the headwaters of the lake and measure runoff from the Williamson River and Sprague River, a tributary of the Williamson. Runoff in the region between WLMSN and LINK is unmeasured and must be estimated to account for total inflow to the lake. A USGS station at Klamath Falls (LINK) gauges only a part of the lake's outflow; data for 

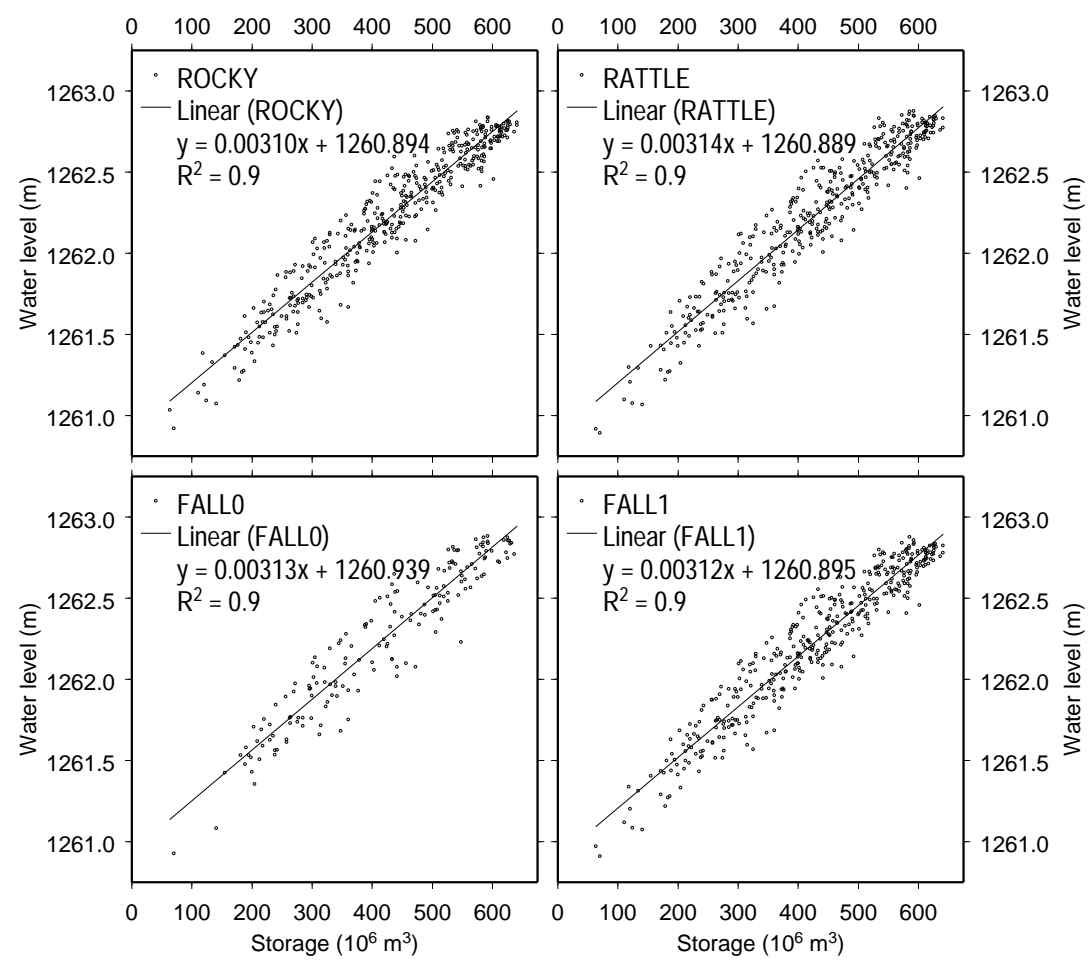

Fig. 2. Stage-storage curves for Upper Klamath Lake.

the remaining portion of the outflow are unavailable. Table 1 also lists the six locations in IL2 at which irrigation and return flows are measured ("A" canal, Lost River Diversion Channel, North Canal, Straits Drain, and Ady Canal at Stateline). These sites are operated by USBR and various irrigation/drainage districts (Risley et al., 2006).

\section{Methodology}

We estimated the effects of irrigation on Upper Klamath Lake water levels using a daily water budget approach:

$D_{s}=A_{\text {lake }} \triangle D=I_{w s}+I_{\text {roff }}+P_{\text {lake }}-E_{\text {lake }}-O_{\text {irr }}-O_{\text {fall }}$

where $D_{s}\left(\mathrm{~m}^{3}\right)$ is lake water storage change; $A_{\text {lake }}\left(\mathrm{m}^{2}\right)$ is lake area; $D(\mathrm{~m})$ is lake water depth; $I_{w s}\left(\mathrm{~m}^{3}\right)$ is daily streamflow from the Williamson River watershed measured at WLMSN; $I_{\text {roff }}\left(\mathrm{m}^{3}\right)$ is unmeasured runoff in the region between USGS stations WLMSN and LINK; $P_{\text {lake }}\left(\mathrm{m}^{3}\right)$ is precipitation over the open water surface of the lake; $E_{\text {lake }}\left(\mathrm{m}^{3}\right)$ is evaporation over the open water surface of the lake; $O_{\text {fall }}$ $\left(\mathrm{m}^{3}\right)$ is regulated outflow from the lake at Klamath Falls to the Klamath River downstream; and $O_{\text {irr }}\left(\mathrm{m}^{3}\right)$ is water withdrawn for irrigation purposes. Because observations were only available for a portion of the lake's outflow, a broadcrested weir equation was used to determine $O_{\text {fall }}$ (Fenton, 1992; Hager and Schwalt, 1994; Fritz and Hager, 1998).

$O_{\text {fall }}=B\left(D-D_{\min }\right)^{3 / 2}$

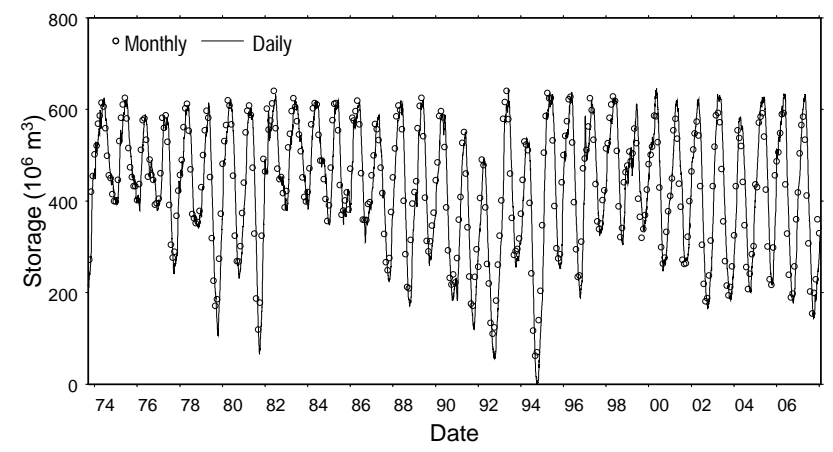

Fig. 3. Recorded monthly and estimated daily storage volumes in Upper Klamath Lake from 1974 to 2008.

where $B$ is an integrated discharge coefficient adjusted to a value of 60 and $D_{\min }(\mathrm{m})$ is the minimum lake water depth set at $0.9 \mathrm{~m}$. A maximum storage level was fixed at $635 \times 10^{6} \mathrm{~m}^{3}$, with excess volumes contributing to lake discharge as $O_{\text {fall }}$.

$O_{\text {irr }}$ was set to equal the net irrigation consumption under various scenarios, as calculated by:

$\mathrm{CON}_{\text {irr }}=\mathrm{ET}_{\text {actual }}-\mathrm{ET}_{\text {natural }}$

where $\mathrm{ET}_{\text {actual }}$ is the actual ET that exists in the irrigable lands under irrigated conditions, and $\mathrm{ET}_{\text {natural }}$ is the hypothetical ET that would exist in the irrigable lands under natural conditions. $\mathrm{ET}_{\text {actual }}, \mathrm{ET}_{\text {natural }}$, and the remaining 
terms in Eq. (1) $\left(I_{\text {roff }}, P_{\text {lake }}\right.$, and $\left.E_{\text {lake }}\right)$ were determined as described below.

The conventional (without irrigation algorithm) VIC macroscale hydrology model (Liang et al., 1994) was employed to simulate the regional hydrology under natural conditions. VIC is a semi-distributed grid-based model that is typical of the land surface schemes now used in many numerical weather prediction and climate models (Mitchell et al., 2004); it does not account for human regulation of streamflow or water diversions. The model is forced with daily precipitation, maximum and minimum temperature, and daily averaged wind speed, which are obtained from the NOAA Cooperative Observer (Co-op) network and processed into model forcing grids at 1/16 degree spatial resolution (Maurer et al., 2002; Tang et al., 2009a). For this study, the VIC model was calibrated with observed streamflow data recorded from 1950 to 2005 at USGS stations SPRGE and WLMSN (Fig. 1). The calibrated model was then used to simulate the unmeasured runoff between stations WLMSN and LINK $\left(I_{\text {roff }}\right)$. $\quad P_{\text {lake }}$ and $E_{\text {lake }}$ were obtained from precipitation and evaporation estimates in grid cells containing open water surfaces. The hypothetical ET that would exist without irrigation ( $\left.\mathrm{ET}_{\text {natural }}\right)$ was calculated in grid cells containing land surfaces by applying the principle of mass conservation to observed precipitation and discharge. The VIC lake algorithm (Hostetler and Bartlein, 1990; Bowling et al., 2000) was used to estimate ET in grid cells containing marsh, wetlands, and lakes.

Although observations of actual ET that exists with irrigation $\left(\mathrm{ET}_{\mathrm{actual}}\right)$ are available, these measurements are sparse, and the combination of hydrological models and satellite data offer opportunities to improve their spatial and temporal resolution. We examined two methods for estimating $\mathrm{ET}_{\text {actual }}$, i.e., total crop water consumption, in those grid cells containing irrigable lands. The first approach employed the VIC irrigation model described by Haddeland et al. (2006). In order to provide a realistic vegetation parameterization, MODIS LAI data (MOD15A2) were directly assimilated into the model for the period 2001 to 2005; prior to 2001, when MODIS data were unavailable, mean monthly MODIS values were assumed. One drawback to this method involves the model's assumptions about how and when irrigation water is added to remove the deficit between the model's simulated soil moisture and field capacity. These assumptions are somewhat difficult to verify in practice and can have a considerable effect on the model's estimate of crop water use.

In contrast, satellite-based methods offer opportunities to estimate actual ET without detailed knowledge of local water data such as soil parameters. This motivated our second approach, which employed the satellite-based ET estimation system developed by Tang et al. (2009b) to retrospectively estimate ET in the irrigation area of the basin (Fig. 1) from 2001 to 2005. The system is based on the MODIS and NOAA/NESDIS SRB products, has daily calculation time steps, and is employed at about a $250 \mathrm{~m}$ spatial resolution.
ET is estimated via a VI- $T_{s}$ diagram method, in which the primary parameters, vegetation index (VI) and surface temperature $\left(T_{S}\right)$ are derived from satellite data (Nemani and Running, 1989; Carlson et al., 1995; Jiang and Islam, 2001).

The VI- $T_{s}$ method works best over areas where there is substantial diversity in vegetation types within the remote sensing window, and hence diversity of VI- $T_{S}$ combinations (Roerink et al., 2000; Courault et al., 2005). This condition is well met by the substantial contrast in VI and $T_{S}$ across the interface between irrigated cropland and surrounding areas (Tang et al., 2009b). Tang et al. (2007) compared ET from the VI- $T_{s}$ method with three AmeriFlux tower observations in California and showed that ET biases can be significantly reduced over long averaging periods, although substantial discrepancies in instantaneous ET estimation remain in savanna and forest ecosystems.

A significant drawback to the VI- $T_{S}$ diagram method is cloud/aerosol contamination of the optical remote sensing data. In the ET estimation system, the vegetation index (i.e., normalized difference vegetation index, NDVI) is calculated from MODIS daily surface reflectance data (MOD09GQ) using an 8-day maximum compositing method; the 16-day maximum compositing vegetation index product (MOD13Q1) is employed as auxiliary data in the case of 8 continuous cloudy days. $T_{S}$ is obtained from the MODIS land surface temperature (LST) product MOD11A1. For days when cloudy conditions prohibit data acquisition, the surface temperature for the closest available day is used instead. Although the surface temperature can have large day-to-day variations, small day-to-day variations of evaporative fraction, defined as the ratio of ET to available energy, and energy conservation effectively constrain errors from this source (Tang et al., 2009b). Because the system uses only satellite data to estimate ET, it is well suited for large-scale regions in which ground observation networks cover only a small portion of the land surface.

Daily ET estimated by the satellite-based system have been found to agree reasonably well with ground Bowen ratio observations in the Upper Klamath River Basin (see Fig. 1), as well as a more sophisticated satellite-based ET mapping system with internalized calibration (METRIC) (Allen et al., 2007; Tang et al., 2009b). The system provides high temporal and spatial resolution estimates of actual water consumption, which describes depletion from all water sources, including precipitation, irrigation, groundwater, and soil moisture in the unsaturated zone. The system simulates ET independently from the models and accounts for human regulation of streamflow and water diversions.

Net irrigation consumption $\left(\mathrm{CON}_{\text {irr }}\right)$ was determined through Eq. (3) by substituting the actual ET estimated by each of these two methods for $\mathrm{ET}_{\text {actual }}$ and the hypothetical ET estimated by the conventional VIC model for $\mathrm{ET}_{\text {natural }}$. In the following discussion, $\mathrm{CON}_{\text {irr }}$ based on actual ET estimated by the VIC irrigation model is referred to as $\mathrm{VIC}_{\mathrm{irr}}$, and $\mathrm{CON}_{\text {irr }}$ based on actual ET estimated by the satellite- 


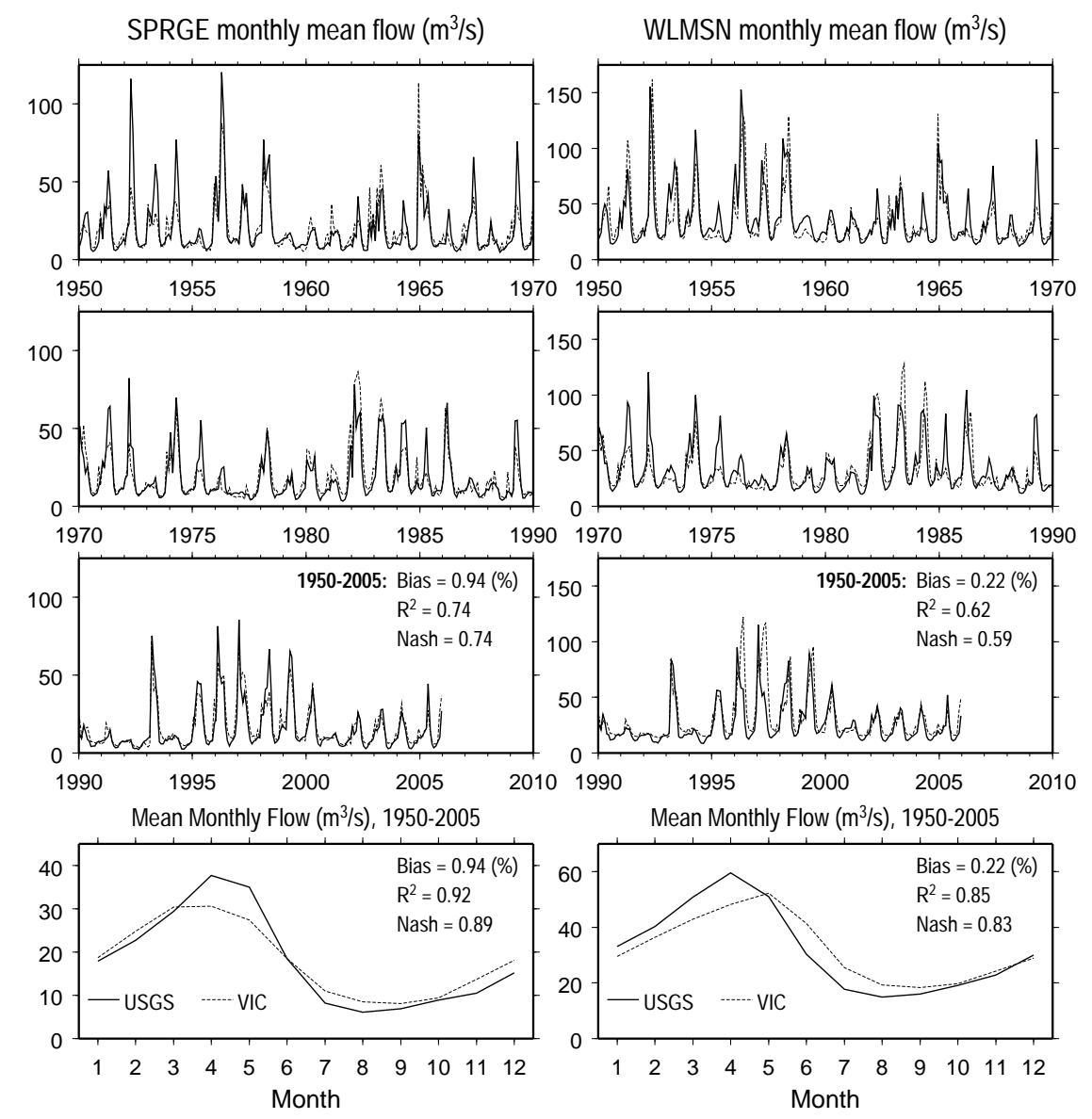

Fig. 4. Results of the conventional VIC model calibration, as demonstrated by simulated and observed streamflow at USGS station SPRGE (left) and WLMSN (right).

based system is referred to as $\mathrm{MOD}_{\text {irr }}$. Four scenarios were designed in order to assess the effects of irrigation on lake water levels. The baseline scenario (Non_IL) assumes that no water is withdrawn from the lake for irrigation (i.e., $O_{\text {irr }}=0$ ). In Scenario IL_1, representing irrigation of the smallest area, $O_{\text {irr }}$ is set to equal the net irrigation consumption in area IL1. Scenario IL_12, which is most representative of actual conditions (see Sect. 2), sets $O_{\text {irr }}$ to equal the net irrigation consumption in areas IL1 and IL2. Scenario IL_123, representing irrigation of the maximum possible area, sets $O_{\text {irr }}$ to equal the net irrigation consumption in areas IL1, IL2, and IL3.

\section{Results and evaluation}

Figure 4 shows streamflow at SPRGE and WLMSN (see Fig. 1 and Table 1) as simulated by the conventional VIC model from 1950 to 2005. Mean monthly simulated streamflows show good agreement with observations, with biases of about $1 \%$ and Nash-Sutcliffe efficiency coefficients (Nash and Sutcliffe, 1970) of 0.89 and 0.83 for each of the two sta-

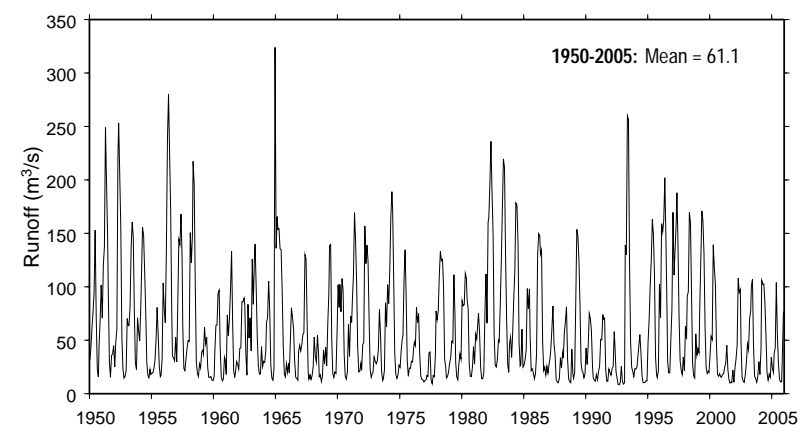

Fig. 5. Simulated surface inflows to Upper Klamath Lake $\left(I_{w s}+I_{\text {roff }}\right)$

tions, respectively. The calibrated model was used to simulate the unmeasured runoff between stations WLMSN and LINK $\left(I_{\text {roff }}\right)$, which was then added to the streamflow observations at WLMSN $\left(I_{w s}\right)$ to generate a time series of total surface inflows to the lake (Fig. 5). The long term mean of these inflows is estimated at $61.1 \mathrm{~m}^{3} / \mathrm{s}$, which differs by 


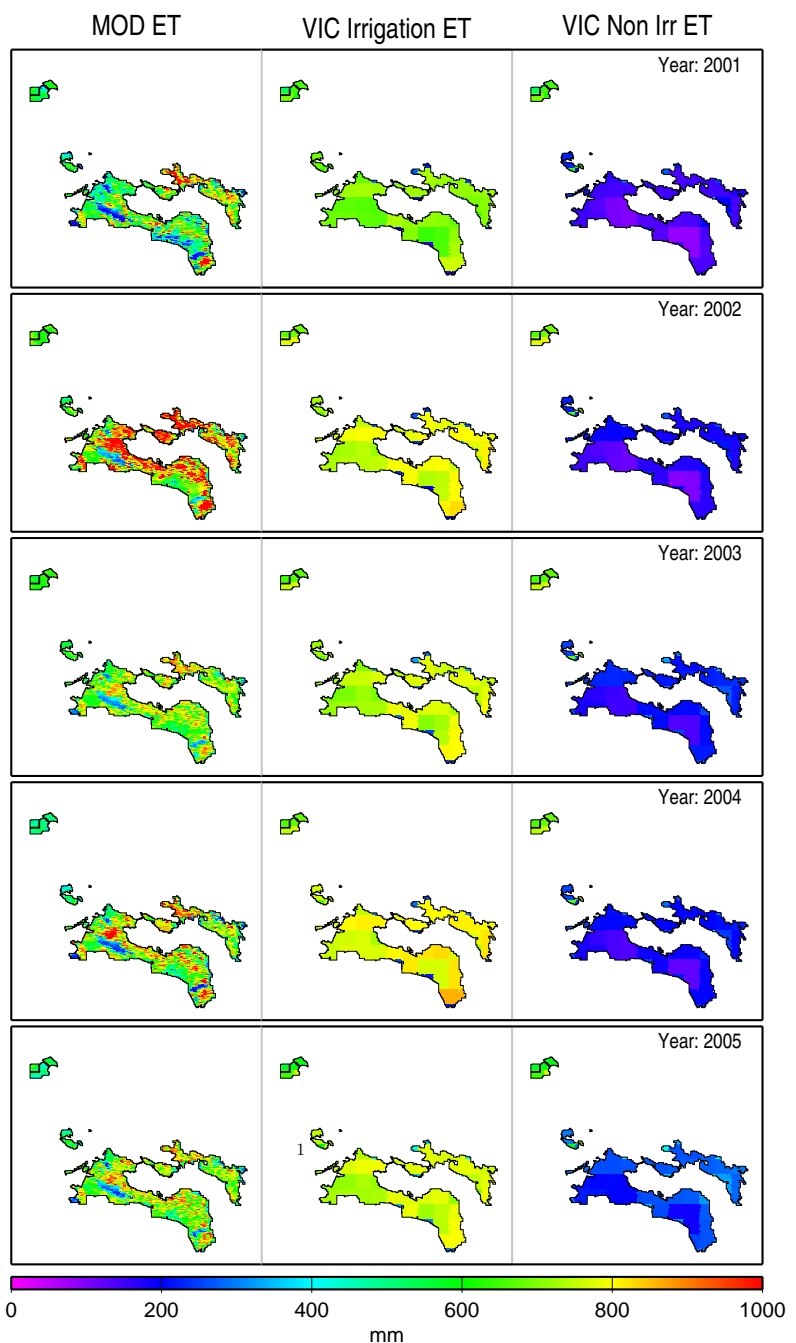

Fig. 6. Spatial distribution of ET in the irrigable lands as estimated by satellite data (left), VIC irrigation model simulations (center), and conventional VIC model simulations (right) from 2001 to 2005. See Fig. 1 for delineation of IL1, IL2, and IL3.

about $1 \%$ when compared with the value of $60.3 \mathrm{~m}^{3} / \mathrm{s}$ that was reported in a detailed USBR investigation of the natural hydrology of the lake (USBR, 2005).

Figure 6 compares spatial distributions of ET in IL1, IL2, and IL3 as estimated by satellite data, VIC irrigation model simulations, and conventional VIC model simulations from 2001 to 2005. As expected, satellite-based estimates of ET are generally higher than conventional VIC model estimates, with differences representing the effects of irrigation. Estimates of ET from VIC irrigation model simulations are comparable to those based on satellite data, although spatial resolution is much lower (1/16 degree, or roughly 5 to $7 \mathrm{~km}$, for VIC vs. $250 \mathrm{~m}$ for MODIS).

Figure 7 shows time series of 8-day ET for the three irrigation areas from 2001 to 2005 . As above, estimates

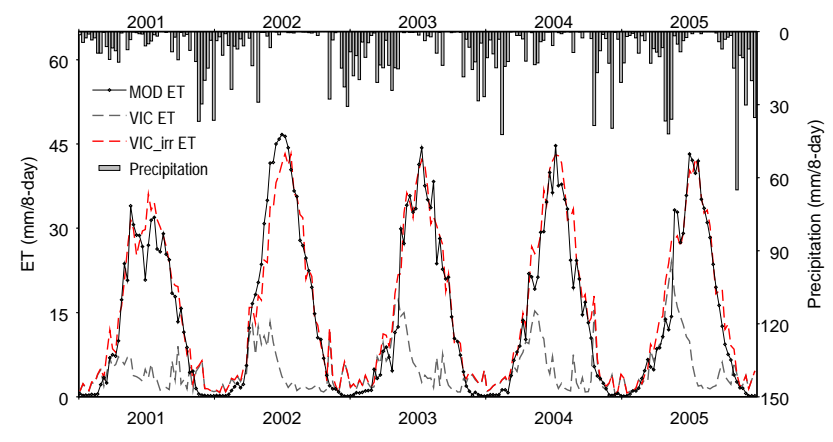

Fig. 7. Time series of ET for the three irrigation areas from 2001 to 2005.

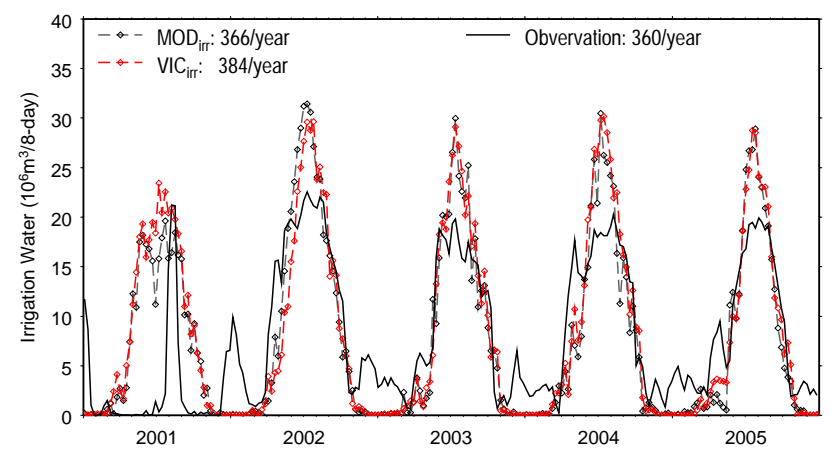

Fig. 8. Time series of estimated net irrigation consumption $\left(\mathrm{MOD}_{\text {irr }}\right.$ and VIC $_{\text {irr }}$ ) and observed net irrigation supply for IL2 from 2001 to 2005. Annual mean values over the period are given in the plot.

of ET based on the VIC irrigation model (with MODIS LAI parameterization) agree closely with satellite-based estimates. Both are significantly higher than conventional VICsimulated estimates during the growing season of May to October, although estimates agree more closely during the high rainfall spring months, when irrigation needs diminish. Differences between satellite-based and conventional VIC model-based estimates of ET were used to determine $\mathrm{MOD}_{\text {irr }}$; differences between VIC irrigation model and conventional VIC model estimates were used to compute $\mathrm{VIC}_{\text {irr }}$. These values provide good indicators of net irrigation consumption, although actual withdrawals from Upper Klamath Lake also depend on conveyance losses and operational restrictions.

Figure 8 shows estimated net irrigation consumption $\left(\mathrm{MOD}_{\text {irr }}\right.$ and $\left.\mathrm{VIC}_{\text {irr }}\right)$ and observed net irrigation supply for IL2 from 2001 to 2005. Net irrigation supply was determined by the difference between measurements of irrigation canal deliveries and return flows, where available (see Table 1). Both MOD irr and $\mathrm{VIC}_{\text {irr }}$ show reasonable agreement with observations in most years, although in general, estimates of net irrigation consumption are larger in summer and smaller in winter than observations of net irrigation 

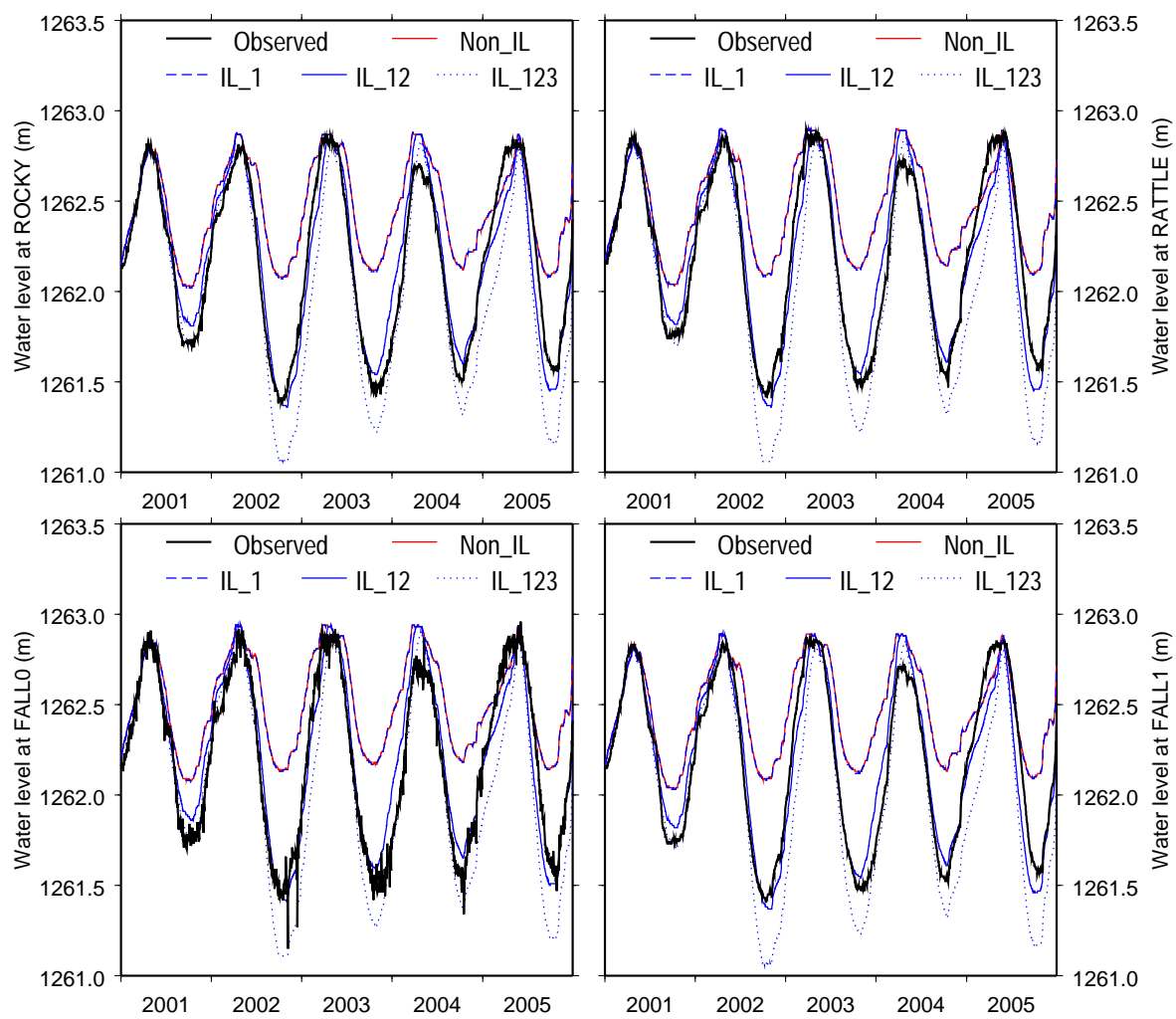

Fig. 9. Simulated and observed water levels at Upper Klamath Lake from 2001 to 2005. The baseline scenario (Non_IL) assumes no irrigation; Scenario IL_1 assumes irrigation for IL1 only; Scenario IL_12 assumes irrigation for IL1 and IL2; and Scenario IL_123 assumes irrigation for IL1, IL2, and IL3.

supply. Despite these discrepancies in timing, total annual net irrigation volumes supplied match up quite well with total annual net irrigation volumes consumed, suggesting that water delivered during the winter is stored in the irrigation area as groundwater or soil moisture, where it remains until consumed by crops during the summer. According to USFWS (2001b), pre-irrigation, or the delivery of water during the winter, is current practice, and is used to enhance the ability of the combined irrigation and cropland system to store water from wet periods to the much drier growing season. The lone recent exception to this practice occurred in the very dry year 2001, when a US District Court order to protect endangered fish restricted irrigation volumes to about half of the estimated demand.

The stage-storage curves in Fig. 2 were used to compute modeled daily water levels at each of the USGS water level gauges, as shown in Fig. 9. For each scenario, $O_{\text {irr }}$ was set to meet net irrigation consumption as estimated by the satellite-based system (MOD ${ }_{\text {irr }}$ ) from 2001 to 2005 and the VIC irrigation model $\left(\mathrm{VIC}_{\text {irr }}\right.$ ) prior to 2001 ; in $2001, O_{\text {irr }}$ was reduced by half to simulate restrictions on water deliveries. Under the baseline scenario (Non_IL), which represents the hydrology under natural conditions, simulated water levels are higher than observed beginning at the start of the ir- rigation period in May. When only IL1 is irrigated (Scenario IL_1), water levels are close to the baseline, indicating that irrigation of this small area has a negligible impact on lake hydrology. When both IL1 and IL2 are irrigated (Scenario IL_12), water levels are lower than the baseline beginning at the start of the irrigation period in May. This scenario is most representative of actual conditions, and as expected, simulated water levels agree most closely with those observed. Scenario IL_123, which assumes irrigation of all three areas, yields the lowest water levels during the growing season. Comparisons of baseline estimates with observations show that irrigation causes an average decline of $0.5 \mathrm{~m}$ in the mean water levels of October, when they are generally at their lowest. Average annual water levels estimated by the baseline scenario $(1262.5 \mathrm{~m})$ are about $0.3 \mathrm{~m}$ higher than those estimated by Scenario IL_12 (1262.2 m). Annual ranges in water levels under the baseline scenario $(0.8 \mathrm{~m})$ are likewise about $0.5 \mathrm{~m}$ lower than those estimated by Scenario IL_12, suggesting impacts on surrounding wetland environments that are influenced by water level fluctuations.

Table 2 gives the simulated annual mean water budget terms for the lake for Scenario IL_12 from 2001 to 2005 and the water storage change (water storage difference between 1 January 2001 and 31 December 2005). Surface runoff 
Table 2. Annual mean water budget terms for Upper Klamath Lake $\left(10^{6} \mathrm{~m}^{3}\right)$ for Scenario IL_12 from 2001 to 2005, and the water storage change $\left(D_{s}\right.$, water storage difference between 1 January 2001 and 31 December 2005).

\begin{tabular}{lllllll}
\hline$I_{w s}$ & $I_{\text {roff }}$ & $P_{\text {lake }}$ & $E_{\text {lake }}$ & $O_{\text {irr }}$ & $O_{\text {fall }}$ & $D_{s}$ \\
\hline 671 & 474 & 166 & 315 & 351 & 629 & 79 \\
\hline
\end{tabular}

$\left(I_{w s}+I_{\text {roff }}\right)$ makes up the majority of lake inflows; precipitation over the open water surface of the lake $\left(P_{\text {lake }}\right)$ is small by comparison. Outflow from the lake $\left(O_{\text {fall }}\right)$, evaporation over the open water surface of the lake $\left(E_{\text {lake }}\right)$, and irrigation water withdrawals $\left(O_{\text {irr }}\right)$ account for $48 \%, 24 \%$, and $27 \%$ of the net inflow to the lake on average, respectively. The simulated water storage on 31 December 2005 is $79 \times 10^{6} \mathrm{~m}^{3}$ (about $6 \%$ of the annual net inflow to the lake) larger than that on 1 January 2001. The water storage change agrees well with the observed change of $86 \times 10^{6} \mathrm{~m}^{3}$.

Simulated and observed monthly mean water budget components are shown in Fig. 10 for Scenario IL_12 from 2001 to 2005. Total lake inflows exceed total lake outflows from October to April, at which point lake storage volume reaches its annual peak. Although high May inflows keep lake levels near peak stage during that month, storage volumes decrease from April to October due to increasing amounts of evaporation and irrigation withdrawals, the latter accounting for the greatest part of lake outflows (48\%) during this period. Total lake outflows are greatest during the months of May, June, and July, decreasing as storage volumes approach the regulated minimum in late summer. Mean monthly simulated storage volumes correspond well with those observed, as do VIC lake model estimates of $E_{\text {lake }}$ with those estimated by USBR (2005). The water budget simulations illustrate the importance of irrigation withdrawals to lake storage volumes, particularly during the high irrigation season of June to September.

Long-term impacts of irrigation on lake hydrology were assessed by estimating net irrigation consumption using the satellite-based system from 2001 to 2005 and VIC irrigation model simulations prior to 2001 when MODIS data do not exist. Figure 11 shows simulated and observed daily water levels at USGS station FALL1, beginning in October 1974 when the earliest observations are available. As before, the baseline scenario (Non_IL) yields larger storage volumes and higher water levels, while Scenario IL_12, which is most representative of actual conditions, agrees better with observed values. Comparisons of baseline estimates with observations show that irrigation causes an average decline of $0.3 \mathrm{~m}$ in the mean water levels in October, with drops of up to $1 \mathrm{~m}$ in some years. Average annual water levels estimated for the baseline scenario $(1262.4 \mathrm{~m})$ are about $0.2 \mathrm{~m}$ higher than those observed and estimated by Scenario IL_12 (1262.2 m).

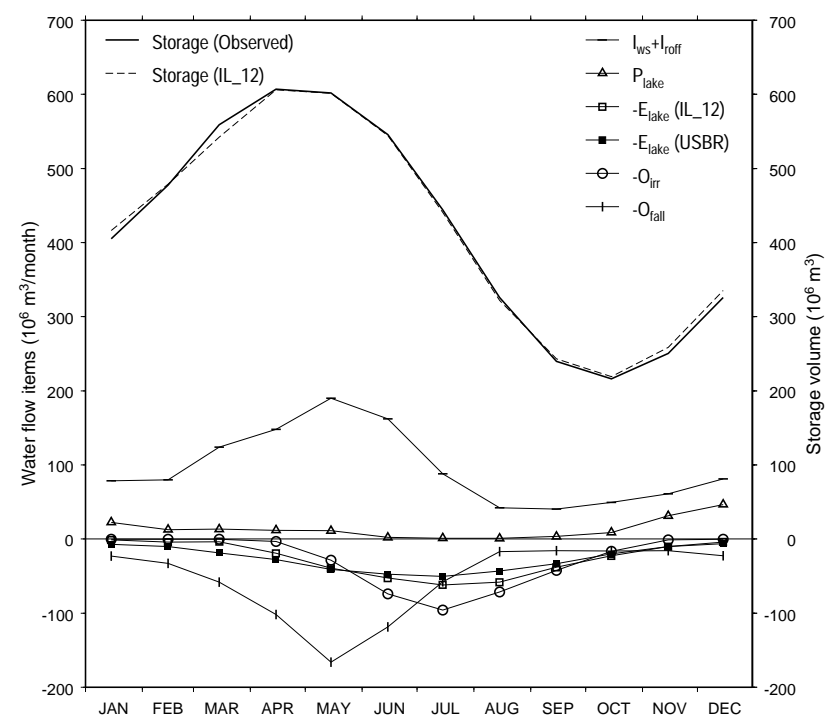

Fig. 10. Simulated and observed monthly mean water budget terms at Upper Klamath Lake for Scenario IL_12 from 2001 to 2005. Total surface inflows are represented by $\left(I_{w s}+I_{\text {roff }}\right)$, precipitation over the open water surface is $P_{\text {lake }}$, evaporation over the open water surface is $E_{\text {lake}}$, water withdrawn for irrigation purposes is $O_{\text {irr }}$, and outflow from the lake to the Klamath River downstream is $O_{\text {fall }}$. Observed storage volumes were obtained from CDEC station KLM.

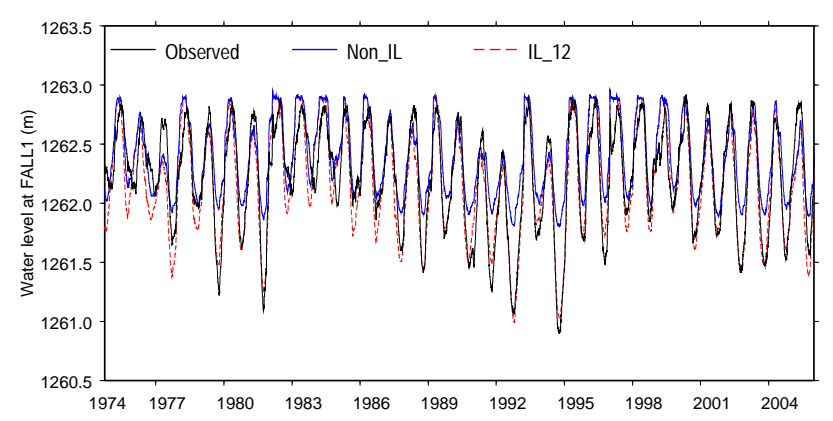

Fig. 11. Simulated and observed daily water levels at USGS station FALL1 from 1974 to 2005. The baseline scenario (Non_IL) assumes no irrigation; Scenario IL_12 assumes irrigation for IL1 and IL2.

Annual ranges in water levels under the baseline scenario are about $0.3 \mathrm{~m}$ lower than those estimated by Scenario IL_12.

\section{Conclusions and discussion}

This paper demonstrates the feasibility of using satellite data and hydrologic models to assess the impacts of irrigation withdrawals on lake hydrology. The conventional VIC model was used to estimate hypothetical crop water usage in the absence of irrigation withdrawals. Since measurements of irrigation withdrawals are limited, these were determined by 
estimates of consumptive irrigation use, which in turn, were derived from the difference between hypothetical and actual estimates of crop water use as determined by a satellite-based ET estimation system (Tang et al., 2009b). Estimates of consumptive irrigation use under a realistic irrigation scenario agree fairly well with observations of net irrigation supply from 2001 to 2005 at Upper Klamath Lake, Oregon.

Model-simulated lake inflows are consistent with streamflow observations and published reports of long-term natural flows (USBR, 2005). Model-simulated lake storage volumes and water levels under a realistic irrigation scenario also agree well with those observed. Simulated baseline (non-irrigation) water levels are greater than those observed on average, while the amplitude of seasonal variations is less than those observed. When combined with the VIC model, the satellite-based ET estimation system shows that irrigation caused a decline of $0.3 \mathrm{~m}$ in mean annual water levels and $0.5 \mathrm{~m}$ in mean October water levels, while leading to an increase of $0.5 \mathrm{~m}$ in annual water level ranges at the lake from 2001 to 2005. Although the use of satellite data is complicated by limited record lengths, model simulations were used to extend these records to 1974 and yielded largely comparable results.

Estimates of crop water consumption can, of course, be made using methods like tower observations or model estimates, such as those provided by the VIC irrigation model. The greatest advantage provided by the ET estimation system described herein is the ability to make such estimates at higher spatial resolutions and without detailed knowledge of the specifics of water supply system operating rules. These estimates are essential for establishing both baseline lake levels and levels under various other irrigation scenarios, which can then be used to mitigate environmental impacts, among other purposes. The satellite-based ET estimation system also provides the potential, when combined with model simulations, to produce realistic estimates of lake water budget terms in real-time, and more efficiently match irrigation withdrawals with demands.

Acknowledgements. The work described in this paper was supported by NASA Grant NNSO6AA78G to the University of Washington.

Edited by: N. Verhoest

Reviewed by: G. d'Urso and Z. Su

\section{References}

Allen, R. G., Tasumi, M., and Trezza, R.: Satellite-based energy balance for mapping rvapotranspiration with internalized calibration (METRIC)-Model, J. Irrig. Drain. E-Asce., 133, 380-394, 2007.

Bastiaanssen, W. G. M., Menenti, M., Feddes, R. A., and Holtslag, A. A. M.: A remote sensing surface energy balance algorithm for land (SEBAL), 1. Formulation, J. Hydrol., 212-213, 198-212, 1998.
Bastiaanssen, W. G. M., Molden, D. J., and Makin, I. W.: Remote sensing for irrigated agriculture: examples from research and possible applications, Agr. Water Manage., 46, 137-155, 2000.

Bastiaanssen, W. G. M., Ahmad, M., and Chemin, Y.: Satellite surveillance of evaporative depletion across the Indus Basin, Water Resour. Res., 38, 1273, doi:10.1029/2001WR000386, 2002.

Bowling, L. C., Cherkauer, K. A., and Lettenmaier, D. P.: Simulation of the effect of lakes and wetland storage on the flow of Arctic rivers, Eos Trans. AGU, 81, Fall Meet. Suppl., 2000.

Carlson, T. N., Gillies, R. R., and Schmugge, T. J.: An interpretation of methodologies for indirect measurement of soil water content, Agr. Forest. Meteorol., 77, 191-205, 1995.

Cleugh, H. A., Leuning, R., Mu, Q., and Running, S. W.: Regional evaporation estimates from flux tower and MODIS satellite data, Remote Sens. Environ., 106, 285-304, doi:10.1016/j.rse.2006. 07.007, 2007.

Courault, D., Seguin, B., and Olioso, A.: Review on estimation of evapotranspiration from remote sensing data: From empirical to numerical modeling approaches, Irrig. Drain., 19, 223-249, 2005.

Döll, P. and Siebert, S.: Global modeling of irrigation water requirements, Water Resour. Res., 38, 1037, doi:10.1029/ 2001WR000355, 2002.

Engman, E. T.: Recent advances in remote sensing in hydrology, US National report to international union of geodesy and geophysics 1991-1994, Rev. Geophys., supplement. AGU, 967-975, 1995.

Fenton, J. D.: Reservoir routing, Hydrol. Sci. J., 37, 233-246, 1992.

Fritz, H. M. and Hager, W. H.: Hydraulics of embankment weirs, J. Hydr. Engrg.-ASCE, 124, 963-972, 1998.

Haddeland, I., Lettenmaier, D. P., and Skaugen, T.: Effects of irrigation on the water and energy balances of the Colorado and Mekong river basins, J. Hydrol., 324, 210-223, doi:10.1016/j. jhydrol.2005.09.028, 2006.

Hager, W. H. and Schwalt, M.: Broad-crested weir, J. Irrig. Drainage Eng-ASCE, 120, 13-26, 1994.

Hostetler, S. W. and Bartlein, P. J.: Simulation of lake evaporation with application to modeling lake level variations of HarneyMalheur Lake, Oregon, Water Resour. Res., 26, 2603-2612, 1990.

Jiang, L. and Islam, S.: Estimation of surface evaporation map over southern Great Plains using remote sensing data, Water Resour. Res., 37, 329-340, 2001.

Lewis, W. M. J.: Klamath Basin fishes: argument is no substitute for evidence, Fisheries, 28, 20-25, 2003.

Liang, X., Lettenmaier, D. P., Wood, E. F., and Burges, S. J.: A simple hydrologically based model of land surface water and energy fluxes for general circulation models, J. Geophys. Res., 99, 14415-14428, 1994.

Maurer, E. P., Wood, A. W., Adam, J. C., Lettenmaier, D. P., and Nijssen, B.: A long-term hydrologically-based data set of land surface fluxes and states for the conterminous United States, J. Climate, 15, 3237-3251, 2002.

Mitchell, K. E., Lohmann, D., Houser, P. R., Wood, E. F., Schaake, J. C., and Robock, A.: The multi-institution North American Land Data Assimilation System (NLDAS): utilizing multiple GCIP products and partners in a continental distributed hydrological modeling system, J. Geophys. Res., 109, 1-32, doi: 10.1029/2003JD003823, 2004.

Mu, Q., Heinsch, F. A., Zhao, M., and Running, S.: Development 
of a global evapotranspiration algorithm based on MODIS and global meteorology data, Rem. Sens. Environ., 111, 519-536, doi:10.1016/j.rse.2007.04.015, 2007.

Nash, J. E. and Sutcliffe, J. V.: River flow forecasting through conceptual models part I - A discussion of principles, J. Geophys. Res., 10, 282-290, 1970.

Neale, C. M. U., Jayanthi, H., and Wright, J. L.: Irrigation water management using high resolution airborne remote sensing, Irrig. Drain., 19, 321-336, 2005.

Nemani, R. R. and Running, S. W.: Estimation of regional surface resistance to evapotranspiration from NDVI and thermal-IR AVHRR data, J. Appl. Meteorol. Climatol., 28, 276-284, 1989.

Nishida, K., Nemani, R. R., Running, S. W., and Glassy, J. M.: An operational remote sensing algorithm of land surface evaporation, J. Geophys. Res., 108, 4270, doi:10.1029/2002JD002062, 2003.

NRC (National Research Council): Endangered and Threatened Fishes in the Klamath River Basin: Causes of Decline and Strategies for Recovery, National Academies Press (US), Washington DC, USA, 397 pp., 2004.

NRC (National Research Council): Hydrology, Ecology, and Fishes of the Klamath River Basin, National Academies Press (US), Washington DC, 249 pp., 2008.

Powers, K., Baldwin, P., Buck, E. H., and Cody, B. A.: Klamath River Basin Issues and Activities: An Overview, CRS Report for Congress, Klamath Falls, 2005.

Risley, J. C., Hess, G. W., and Fisher, B. J.: Assessment of Flow Data from Klamath River Sites Between Link River Dam and Keno Dam, South-Central Oregon, United States Geological Survey, 2006.

Roerink, G. J., Su, Z., and Menenti, M.: S-SEBI: A simple remote sensing algorithm to estimate the surface energy balance, Phys. Chem. Earth Pt. B, 25, 147-157, 2000.

Stewart, J. B., Watts, C. J., Rodriguez, J. C., de Bruin, H. A. R., van de Berg, A. R., and Garatuza-Payan, J.: Use of satellite data to estimate radiation and evaporation for northwest Mexico, Agr. Water. Manage., 38, 181-193, 1999.
Tang, Q., Oki, T., and Kanae, S.: A distributed biosphere hydrological model (DBHM) for large river basin, Ann. J. Hydraul. Eng. JSCE, 50, 37-42, 2006.

Tang, Q., Oki, T., Kanae, S., and Hu, H.: The influence of precipitation variability and partial irrigation within grid cells on a hydrological simulation, J. Hydrometeorol., 8, 499-512, doi: 10.1175/JHM589.1, 2007.

Tang, Q., Wood, A. W., and Lettenmaier, D. P.: Near real time evapotranspiration estimation using remote sensing data, Eos Trans. AGU, 88, Fall Meet. Suppl., H31A-0127, 2007.

Tang, Q., Wood, A. W., and Lettenmaier, D. P.: Real-time precipitation estimation based on index station percentiles, J. Hydrometeorol., 10, 266-277, doi:10.1175/2008JHM1017.1, 2009a.

Tang, Q., Peterson, S., Cuenca, R. H., Hagimoto, Y., and Lettenmaier, D. P.: Satellite-based near-real-time estimation of irrigated crop water consumption, J. Geophys. Res., 114, D05114, doi:10.1029/2008JD010854, 2009b.

USBR (US Bureau of Reclamation): Final Biological Assessment - The Effects of Proposed Actions Related to Klamath Project Operation (1 April 2002-31 March 2012) on Federally Listed Threatened and Endangered Species, US Department of the Interior, Bureau of Reclamation, Mid-Pacific Region, Klamath Basin Area Office, 2002.

USBR (US Bureau of Reclamation): Natural Flow of the Upper Klamath River, US Department of the Interior, Bureau of Reclamation, 2005.

USFWS (US Fish and Wildlife Service): Biological/Conference Opinion Regarding the Effects of Operation of the Bureau of Reclamations Klamath Project on the Endangered Lost River Sucker, Deltistes Luxatus, Endangered Shortnose Sucker, Chasmistes Brevirostris, Threatened Bald Eagle ,Haliaeetus Leucocephalus, and Proposed Critical Habitat for the Lost River/Shortnose Suckers, US Fish and Wildlife Service, Klamath Falls, OR, 2001a.

USFWS (US Fish and Wildlife Service): Wildland Fire Management Plan Klamath Basin National Wildlife Refuge Complex, US Fish and Wildlife Service, Tulelake, CA, 411 pp., http: //www.fws.gov/fire/fmp/region1/oregon/, 2001b. 